\title{
Influence of nitrogen on sown and ratooned upland kangkong (Ipomoea aquatica Forsk.) at two planting densities
}

\author{
A. R. Linnemann, J. M. Louwen, G. H. M. B. Straver and E. Westphal \\ Department of Tropical Crop Science, Agricultural University, P.O. Box 341, 6700 \\ AH Wageningen, Netherlands
}

Received 7 March 1985; accepted 7 May 1985

Key words: kangkong, nitrogen fertilization, yield, nitrate content, leaf vegetable, Ipomoea aquatica

\begin{abstract}
In the summer of 1982 an experiment with kangkong (Ipomoea aquatica Forsk.) was conducted in a glasshouse in the Netherlands. Four levels of nitrogen fertilization, two planting densities and two different cropping methods were tried.

The levels of nitrogen fertilization were $100,250,500$ and $750 \mathrm{~kg} \mathrm{ha}^{-1}$. In comparison with the fresh yield obtained at a level of $100 \mathrm{~kg} \mathrm{ha}^{-1}$ an increase was found of $3.8,5.1$ and $6.1 \mathrm{~kg} \mathrm{~m}^{-2}$ for the crops grown at 250,500 and $750 \mathrm{~kg} \mathrm{ha}^{-1}$ respectively at the end of the 18-weeks trial period. The two planting densities were 44 plants $\mathrm{m}^{-2}(15.0 \mathrm{~cm} \times 15.0 \mathrm{~cm})$ and 20 plants $\mathrm{m}^{-2}(22.5 \mathrm{~cm} \times 22.5 \mathrm{~cm})$. The high planting density exceeded the low planting density in yield by about $3 \mathrm{~kg}$ fresh produce per $\mathrm{m}^{2}$ after 18 weeks. The crop was either ratooned (ratoon method) or resown after harvest (seed method). At the end of the trial period the average difference in fresh weight in favour of the ratoon method was ca $5 \mathrm{~kg} \mathrm{~m}^{-2}$. The average nitrate content increased from $599 \mathrm{mg} \mathrm{kg}^{-1}$ fresh produce for the crop obtained at the lowest nitrogen level to $3812 \mathrm{mg} \mathrm{kg}^{-1}$ at the highest nitrogen level. Stems had much higher nitrate contents than leaves.
\end{abstract}

\section{Introduction}

Kangkong (Ipomoea aquatica Forsk., Convolvulaceae) is a popular leaf vegetable throughout Southeast Asia. Stems as well as leaves are eaten, although some consumers prefer stems while others like leaves better. The vegetable is a valuable source of provitamin A, iron, calcium and phosphorus. Kangkong is grown in moist soil and in aquatic culture. Large differences can be found between descriptions of cultural practices in the literature. This diversity among authors is the result of differences in cultivation between the regions they describe and the fact that only few experiments have been carried out to try and find optimum growing conditions for 
kangkong (Cornelis et al., 1985).

It is well known that nitrogen fertilization enhances the content of nitrate in leafy vegetables. The consumption of large amounts of nitrate is detrimental to human health. In different European countries the maximum accepted content varies from $1200 \mathrm{mg}$ to $4000 \mathrm{mg}$ per $\mathrm{kg}$ fresh weight (Aldershoff, 1982). The relationship between nitrogen fertilization and nitrate content in kangkong has been investigated by Schmidt et al. (1971) and by Purushothaman et al. (1980). Schmidt et al. (1971) found contents of $240 \mathrm{mg}$ to $390 \mathrm{mg}$ nitrate per $\mathrm{kg}$ fresh weight at a moderate and a high nitrogen fertilization level. Purushothaman et al. (1980) recorded $50 \mathrm{mg}$ to $1000 \mathrm{mg}$ nitrate per $\mathrm{kg}$ fresh weight at $\mathrm{N}$ fertilization levels of 0 to $300 \mathrm{~kg} \mathrm{ha}^{-1}$ per crop.

\section{Materials and methods}

This experiment with upland kangkong was conducted for a period of 18 weeks from May to September 1982 on a sandy soil in a glasshouse of the Experimental Farm of the Agricultural University in Swifterbant, Netherlands. The cultivar used was 'Large Leaf' of the Known You Seed Company, Taiwan. In the experiment four levels of nitrogen fertilization, two planting densities and two different cropping methods were tried in a $4 \times 2 \times 2$ factorial experiment replicated five times. The nitrogen levels were $100,250,500$ and $750 \mathrm{~kg} \mathrm{ha}^{-1}$. These amounts were applied to the experimental plots as calcium ammonium nitrate $\left(\mathrm{NH}_{4} \mathrm{NO}_{3}+\mathrm{CaCO}_{3}\right.$, $26 \% \mathrm{~N}$ ) in six equal, partial doses with intervals of three weeks; the first dose just before sowing. The two planting densities were 44 plants $\mathrm{m}^{-2}(15.0 \mathrm{~cm} \times 15.0 \mathrm{~cm})$ and 20 plants $\mathrm{m}^{-2}(22.5 \mathrm{~cm} \times 22.5 \mathrm{~cm})$. The cropping method was either ratooning (cutting plants at ca $5 \mathrm{~cm}$ above soil surface) or harvesting whole plants (cutting at ca $5 \mathrm{~cm}$ above soil surface and uprooting the stubbles) and resowing the cleared plots. The latter method will be referred to in this paper as the seed method. Seeds were treated with concentrated sulphuric acid for $3 \mathrm{~min}$., washed and sown in Jiffy9 pots. Seedlings were transplanted after a week to obtain a homogeneous crop; on farmers' fields transplanting is not a common practice. The size of the experimental plots was $90 \times 90 \mathrm{~cm}$; thus resulting in 16 plants per plot for the low planting density and 36 for the high planting density. Plants were watered daily by overhead sprinkling. Based on an analysis of a soil sample, nutrients other than nitrogen were applied as a basal dressing at the beginning of the experiment: $P_{2} O_{5} 1000 \mathrm{~kg} \mathrm{ha}^{-1}$ as triple superphosphate $\left(46 \% \mathrm{P}_{2} \mathrm{O}_{5}\right)$ and $\mathrm{K}_{2} \mathrm{O} 1000 \mathrm{~kg} \mathrm{ha}^{-1}$ as sulphate of potashmagnesia $\left(\mathrm{K}_{2} \mathrm{SO}_{4} \cdot \mathrm{MgSO}_{4} \cdot 6 \mathrm{H}_{2} \mathrm{O} ; 28 \% \mathrm{~K}_{2} \mathrm{O}\right.$ and $\left.9 \% \mathrm{MgO}\right)$ and two top dressings of $500 \mathrm{~kg} \mathrm{ha}^{-1}$ for $\mathrm{P}_{2} \mathrm{O}_{5}$ and $\mathrm{K}_{2} \mathrm{O}$ each. The first top dressing was applied six weeks after the start of the experiment and the second after twelve weeks. After each harvest insecticides were applied against aphids and white flies. Day temperatures recorded throughout the experiment varied from $25^{\circ} \mathrm{C}$ to $35^{\circ} \mathrm{C}$, night temperatures from $23{ }^{\circ} \mathrm{C}$ to $26{ }^{\circ} \mathrm{C}$. The relative humidity during daytime was $30-60 \%$, during nighttime $55-80 \%$. The average amount of solar radiation received by the crop in the glasshouse per day was 0.6 times the solar radiation outdoors, i.e. about $1000 \mathrm{~J}$ $\mathrm{cm}^{-2}$. 
The first harvest for all treatments took place six weeks after sowing. Thereafter the ratoon crop could be harvested once every three weeks because of its short period of regrowth, while the seed method produced a crop once every six weeks. This resulted in five marketable crops using the ratoon method, and in three for the seed method by the end of the 18 -week trial period. Border rows of all experimental plots were discarded, thus data were collected from 4 plants at the low and from 16 plants at the high planting density. All plants were weighed to determine the total fresh weight. Samples of 100-200 g were separated into stems plus petioles and leafblades, and dried at $105^{\circ} \mathrm{C}$ to determine dry matter content and total dry weight. Of the samples mentioned the number of stems per plant and the leaf:stem ratio (dry as well as fresh) were recorded to describe crop quality. For the nitrate content, for the plots with high planting density (replicates 2, 4 and 5) only, separate samples of ca $100 \mathrm{~g}$ stems plus petioles and $100 \mathrm{~g}$ leaf-blades, were dried at $70^{\circ} \mathrm{C}$ for twelve hours and ground. Before nitrate analysis the plant material was again dried at $70^{\circ} \mathrm{C}$. The nitrate was extracted with acetic acid $(0.5 \mathrm{~mol} / \mathrm{l})$ and analysed at the laboratory of the Department of Soil Science and Plant Nutrition of the Agricultural University in Wageningen. The nitrate results were expressed as mmol kg-1 dry matter and recalculated as $\mathrm{mg} \mathrm{kg}^{-1}$ fresh weight.

Data were statistically analysed with the computer package 'Genstat'. The output gives a regression analysis and $F$ values at $P<0.05$.

\section{Results}

In Fig. 1 total fresh weight at the end of the trial period is given at the different levels of nitrogen fertilization. For the ratoon method these figures represent total yield of five harvests, for the seed method yields of three harvests. Differences are significant at $P<0.05$. All curves show an increase in yield due to nitrogen application with diminishing returns at the higher levels. It is evident that with the ratoon method significantly higher yields are obtained than with the seed method. Average differences in fresh weight are ca $5 \mathrm{~kg} \mathrm{~m}^{-2}$ at the end of the 18 -week trial period. Also, high planting densities result in higher yields against low planting densities; at the end of the experiment average differences in fresh weight are ca $3 \mathrm{~kg} \mathrm{~m}^{-2}$. Increase in fresh yield per $\mathrm{kg}$ nitrogen of $25.4,5.1$ and $4.2 \mathrm{~g} \mathrm{~m}^{-2}$ is found for nitrogen applications of $100-250,250-500$ and $500-750 \mathrm{~kg} \mathrm{ha}^{-1}$, respectively, thus indicating that with a nitrogen dressing of $750 \mathrm{~kg} \mathrm{ha}^{-1}$ the maximum yield is not obtained.

Data for the last harvest, i.e. the fifth for the ratoon method and the third for the seed method, are presented in Fig. 2 to show differences between the two cropping methods. For the seed method the curves in this figure are similar to those in Fig. 1. For the ratoon method with its remaining stubbles, evidently a nitrogen dressing of $250 \mathrm{~kg} \mathrm{ha}^{-1}$ results in the highest yield. F values due to the effect of nitrogen fertilization are, for the first, third and fifth separate harvests 48.1, 36.1 and 7.6, respectively. The effect of nitrogen application on fresh yield, while still significant, becomes less pronounced over time. At the second and fourth harvest, when only a ratoon crop was harvested, F values are 30.1 and 2.9 , respectively. This indicates that the effect of nitrogen application for the ratoon method is less pronounced than for 


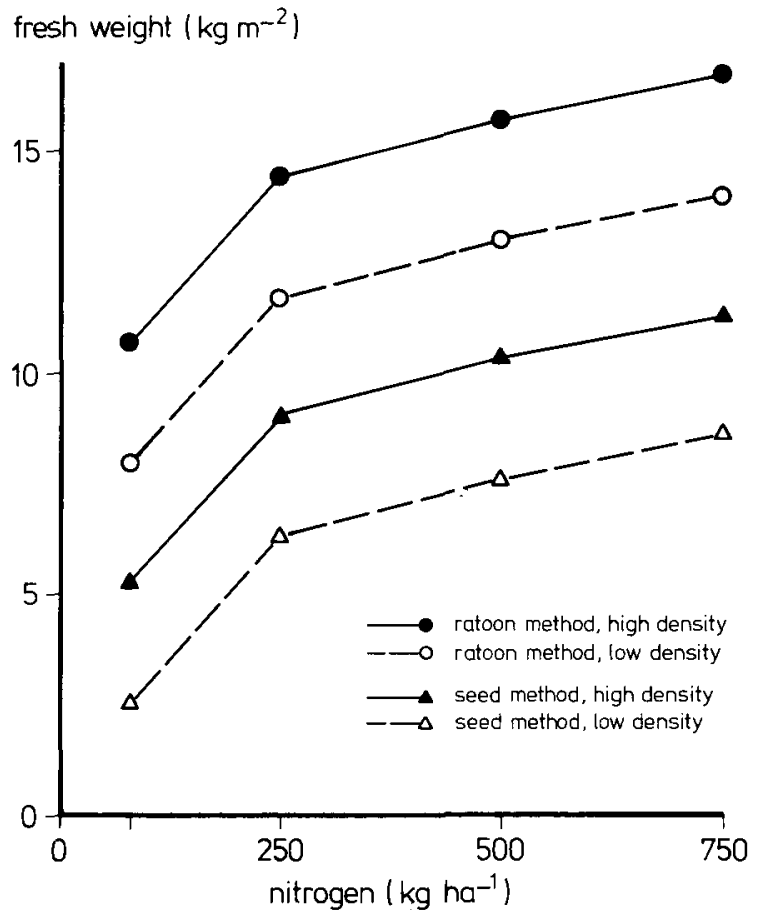

fresh weight $\left(\mathrm{kg} \mathrm{m}^{-2}\right)$

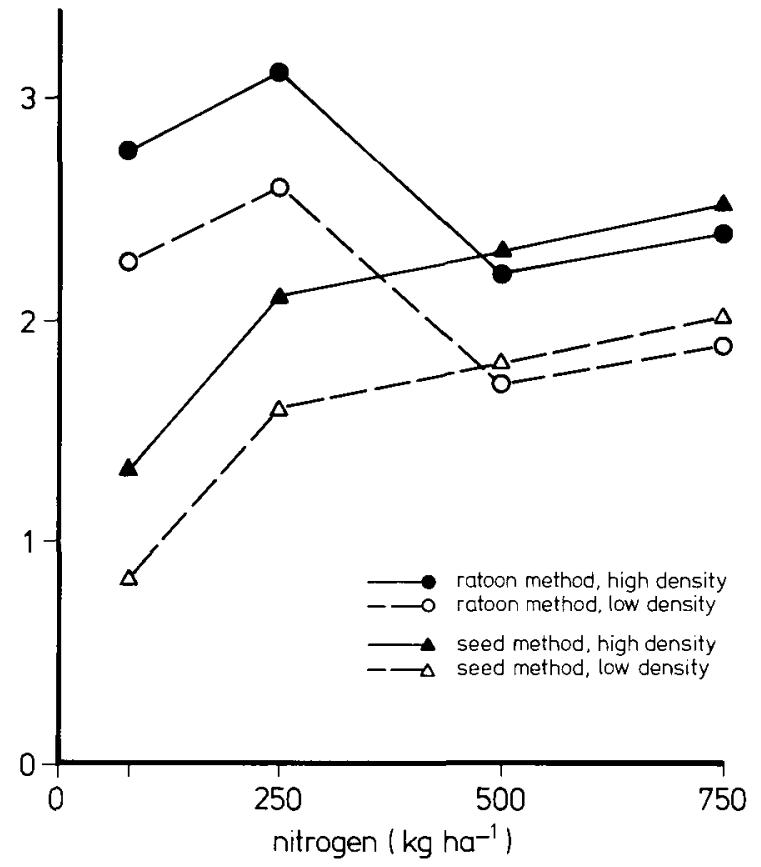

Fig. 1. Total fresh weight $\left(\mathrm{kg} \mathrm{m}^{-2}\right)$ of kangkong at different nitrogen levels $\left(\mathrm{kg} \mathrm{ha}^{-1}\right)$ after 18 weeks for the ratoon and seed methods at low and high planting densities.
Fig. 2. Fresh weight $\left(\mathrm{kg} \mathrm{m}^{-2}\right)$ of kangkong at different nitrogen levels (kg ha-1) for the fifht harvest by the ratoon methods and for the third harvest by the seed method, both at low and high planting densities. 
the seed method.

The effect of planting density on fresh yield for the first, third and fifth harvest is significant with $F$ values of $64.6,26.7$ and 29.5 , respectively. At the second and fourth harvest, when only a ratoon crop was harvested, F values are 22.1 and 2.4; the latter figure is not significant. The fact that the effect of planting density for the ratoon method is not significant at the fourth harvest can be attributed to a larger increase in tillering at the low than at the high planting density. Obviously this increase in stubble can compensate for the wider spacing of the plants.

At the time of the first harvest a significant interaction between nitrogen fertilization and planting density is found. In Fig. 3 fresh weight of the first harvest at the different nitrogen levels is given for both planting densities. In the graph the interaction becomes visible by diverging curves. This interaction indicates that at the low planting density plants hardly influence each other and that more space and fertilizer is available than can be used.

Stems plus petioles and leaf-blades of kangkong differ in their nitrate contents and nitrogen dressings give increases in nitrate, especially in stems plus petioles (Fig. 4). The average nitrate content of the crop obtained at a nitrogen fertilization level of $100 \mathrm{~kg} \mathrm{ha}^{-1}$ is $599 \mathrm{mg} \mathrm{kg}^{-1}$ fresh weight. At levels of 250,500 and $750 \mathrm{~kg} \mathrm{ha}^{-1}$ the nitrate contents are 1617,3011 and $3812 \mathrm{mg} \mathrm{kg}^{-1}$ fresh weight, respectively.

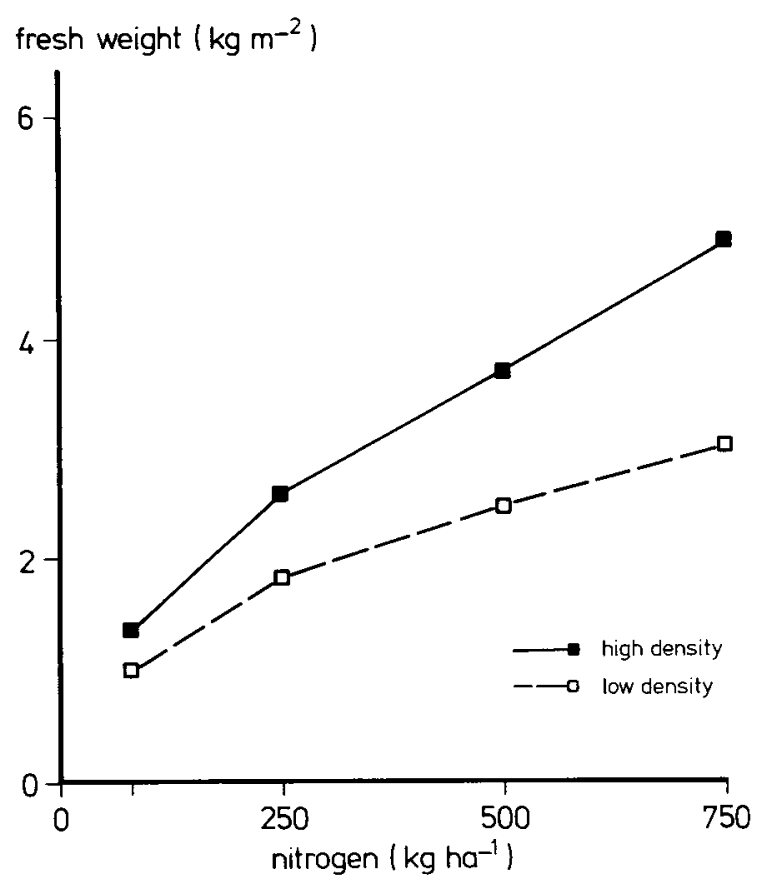

Fig. 3. Fresh weight $\left(\mathrm{kg} \mathrm{m}^{-2}\right)$ of kangkong for the first harvest with different nitrogen levels $\left(\mathrm{kg} \mathrm{ha}^{-1}\right)$ at low and high planting densities. 


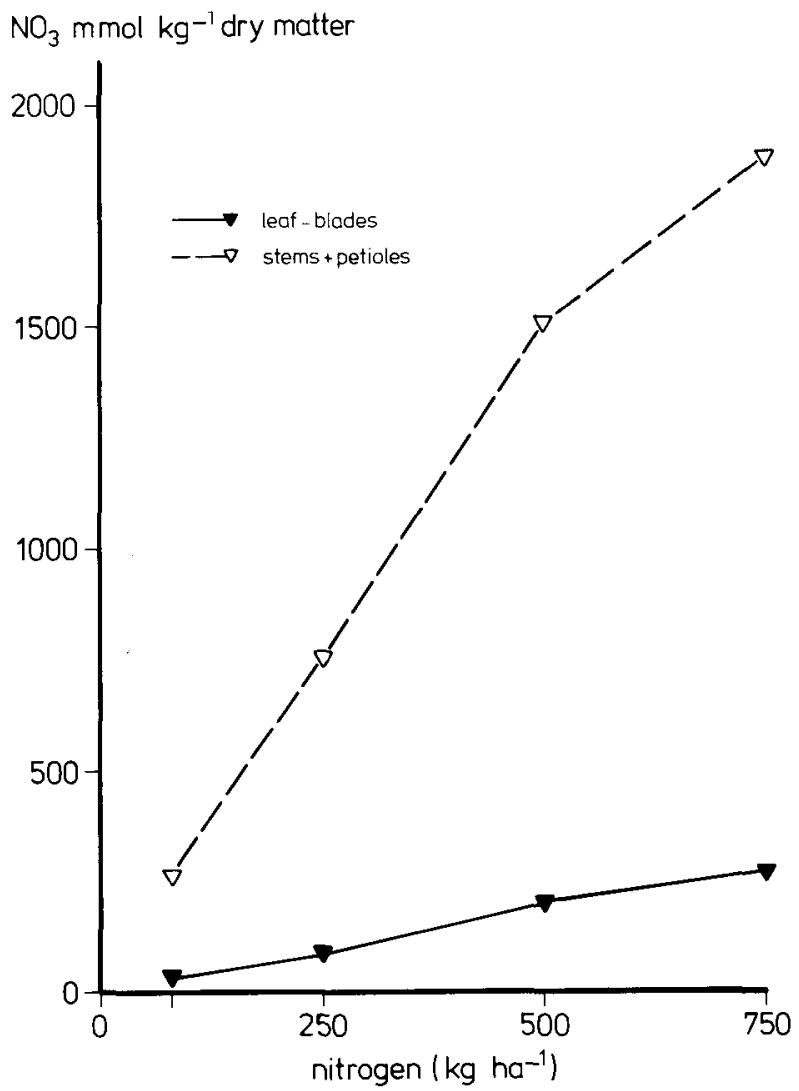

Fig. 4. Nitrate content (mmol kg-1 dry matter) of kangkong stems plus petioles and leaf-blades at different nitrogen levels $\left(\mathrm{kg} \mathrm{ha}^{-1}\right)$.

I hus, only at a nitrogen level of $100 \mathrm{~kg} \mathrm{ha}^{-1}$ does the nitrate content of the harvested crop not exceed the most cautious recommendation.

In this experiment dry matter content for leaf-blades vary from $8.5 \%$ to $8.8 \%$ and for stems plus petioles from $4.3 \%$ to $6.7 \%$, differences between leaf-blades and stems plus petioles being significant. The dry matter content of stems plus pe-

Table 1. Average dry matter content (\%) of stems plus petioles in cropping methods at different levels of nitrogen (differences significant at $P<0.05$ ).

\begin{tabular}{lrrrr}
\hline Cropping method & \multicolumn{4}{l}{ Nitrogen $\left(\mathrm{kg} \mathrm{ha}^{-1}\right)$} \\
\cline { 2 - 5 } & 100 & 250 & 500 & 750 \\
Seed & 6.7 & 5.8 & 5.2 & 5.0 \\
Ratoon & 6.0 & 5.1 & 4.5 & 4.3 \\
\hline
\end{tabular}


Table 2. Average leaf: stem ratios (fresh and dry weight) at different levels of nitrogen (differences significant at $P<0.05$ ).

\begin{tabular}{llrll}
\hline & \multicolumn{4}{l}{ Nitrogen $\left(\mathrm{kg} \mathrm{ha}^{-1}\right)$} \\
\cline { 2 - 5 } & 100 & 250 & 500 & 750 \\
Fresh weight & 1.0 & 0.8 & 0.7 & 0.6 \\
Dry weight & 1.4 & 1.2 & 1.2 & 1.1 \\
\hline
\end{tabular}

tioles decreases with increasing amounts of nitrogen. The seed method leads to higher dry matter content than the ratoon method (Table 1).

The leaf:stem ratios based on fresh as well as on dry weight are presented at different nitrogen levels (Table 2). The dry weight leaf:stem ratio is higher than the fresh weight leaf:stem ratio because of differences in dry matter content between

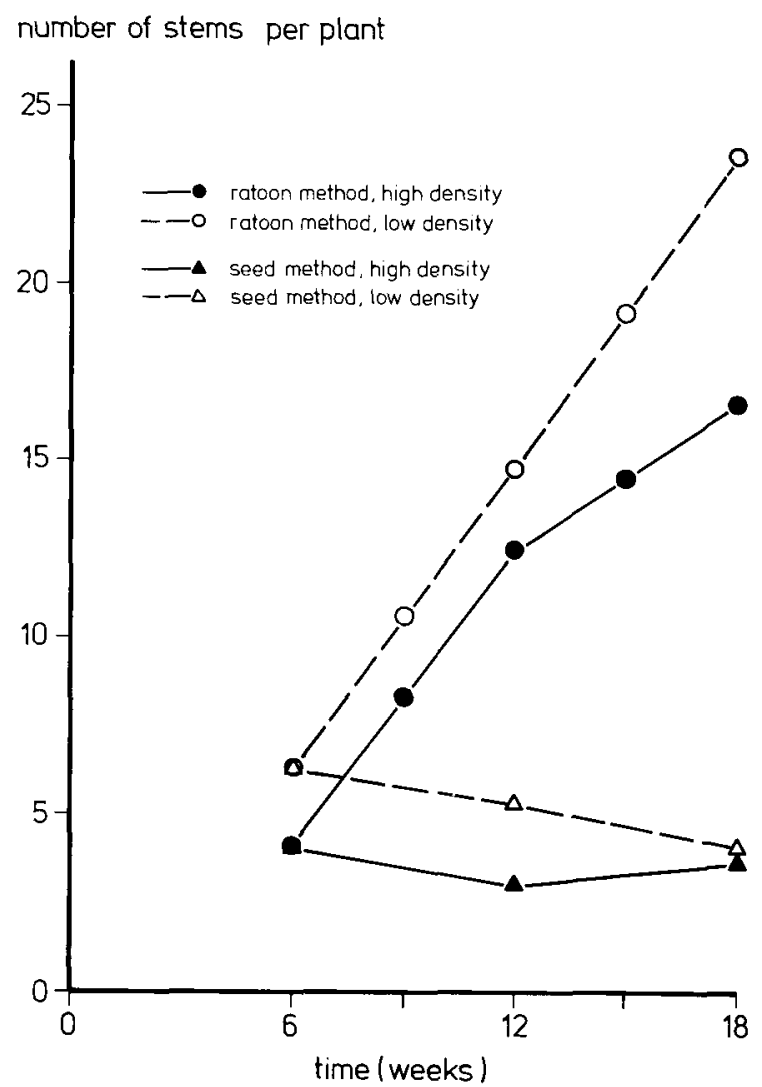

Fig. 5. Number of stems per kangkong plant in the course of time for the ratoon and seed methods at low and high planting densities. 
leaf-blades and stems plus petioles, as seen above. The leaf:stem ratios decrease with increasing amounts of nitrogen, so more stem plus petiole material is produced.

The number of stems per plant increases during the growth period for the ratoon method with ca 5 stems per harvest; the number is above average at low planting density and below average at high planting density (Fig. 5). The differences between planting densities level off yield differences.

\section{Discussion and conclusions}

The highest amount of nitrogen fertilization, i.e. $750 \mathrm{~kg} \mathrm{ha}^{-1}$, resulted in the highest total yields of kangkong at the end of the 18-week trial period. The largest increase in fresh produce of $25.4 \mathrm{~g} \mathrm{~m}^{-2}$ per $\mathrm{kg}$ nitrogen was obtained by increasing nitrogen from 100 to $250 \mathrm{~kg} \mathrm{ha}^{-1}$. The maximum yield under conditions of this experiment was not reached. This conclusion holds for total yield as well as for separate harvests with the seed method. However, for the fourth and the fifth separate harvest of the ratoon method maximum yields were obtained at a nitrogen fertilization level of $250 \mathrm{~kg} \mathrm{ha}^{-1}$. This difference is not well understood. Stubbles of the heavily fertilized plants might be more susceptible to diseases and/or high salt concentrations in the upper soil layers.

For ratooning a much lower amount of nitrogen is sufficient to ensure good crop growth; with the beneficial effect of nitrogen decreasing over time, a diminishing amount of nitrogen should be advised for successive crops.

Higher levels of nitrogen fertilization do not solely increase yields; leaf:stem ratios and dry matter content, especially of stems plus petioles, are decreased while nitrate content increases. The increase of the nitrate content is of particular interest since it is only at a nitrogen level of $100 \mathrm{~kg} \mathrm{ha}^{-1}$ that the nitrate content of kangkong remains below the most cautious European standard. Therefore the amount of nitrogen available in the soil plus that provided as fertilizers should be monitored carefully to avoid unacceptably high amounts of nitrate in the produce. Compared with the nitrate content of $50-1000 \mathrm{mg} \mathrm{kg}^{-1}$ fresh weight found by other authors ( $\mathrm{Pu}-$ rushothaman et al., 1980; Schmidt et al., 1971) values found in this experiment, $600-3800 \mathrm{mg} \mathrm{kg}^{-1}$ fresh weight, are rather high.

High planting density gave higher yields than low planting density for total yields as well as for yields of single harvests, except the fourth one. The differences in yield were more important with the seed method than with the ratoon method; tillering in the ratoon crop compensated for the wider spacing at the end of the growing period. This signifies that an optimum planting density is more important with the seed method than when ratooning is practised.

The separate harvests of the ratoon method and those of the seed method did not differ significantly in yield. Nevertheless, substantially higher total yields were achieved with the ratoon method, since in the same period of time five marketable crops were obtained against three with seed cropping. It should be mentioned, however, that in practice differences in yield between the ratoon and the seed method may be less than in this experiment, because in the 18 -week trial period more seed 
crops could have been grown than the three fixed in this experiment. In spite of the higher yields of the ratoon method, farmers may have their own reasons for growing kangkong by the seed method, one of these reasons being a better suitability to their cropping pattern in general.

\section{Acknowledgements}

The authors wish to thank Dr Ir G. J. H. Grubben, Dr Ir M. A. J. van Montfort, Dr Ir J. H. G. Slangen and Ir H. H. H. Titulaer for advice and the staff of the Experimental Farm of the Agricultural University in Swifterbant for technical assistance.

\section{References}

Aldershoff, W. G., 1982. Nitraat in groenten en onze gezondheid. Bedrijfsontwikkeling 13 (3): 273-280.

Cornelis, J., J. A. Nugteren \& E. Westphal, 1985. Kangkong (Ipomoea aquatica Forsk.): an important leaf vegetable in Southeast Asia. Abstracts on Tropical Agriculture 10 (4): 9-21.

Purushothaman, V., A. W. Ahmad \& A. A. Ravoof, 1980. Influence of $\mathrm{N}$ sources and levels on $\mathrm{NO}_{3}-\mathrm{N}$ concentration of two tropical leaf vegetables grown on oligotrophic peat in Malaysia. Vegetables for the hot humid tropics 5: 45-52.

Schmidt, D. R., H. A. McDonald \& F. E. Brockman, 1971. Oxalate and nitrate contents of four tropical leafy vegetables grown at two soil fertility levels. Agronomy Journal 63: 559-561. 